\title{
Preoperative planning and breast implant selection for volume difference management in asymmetrical breasts
}

\author{
Umar Daraz Khan \\ Reshape Clinic, Reshape House, West Malling ME19 6QR, UK.
}

Correspondence to: Dr. Umar Daraz Khan, Plastic Aesthetic Surgeon, Reshape Clinic, Reshape House, West Malling ME19 6QR, Kent, UK. E-mail: Mrumarkhan@aol.com

How to cite this article: Khan UD. Preoperative planning and breast implant selection for volume difference management in asymmetrical breasts. Plast Aesthet Res 2017;4:108-15.

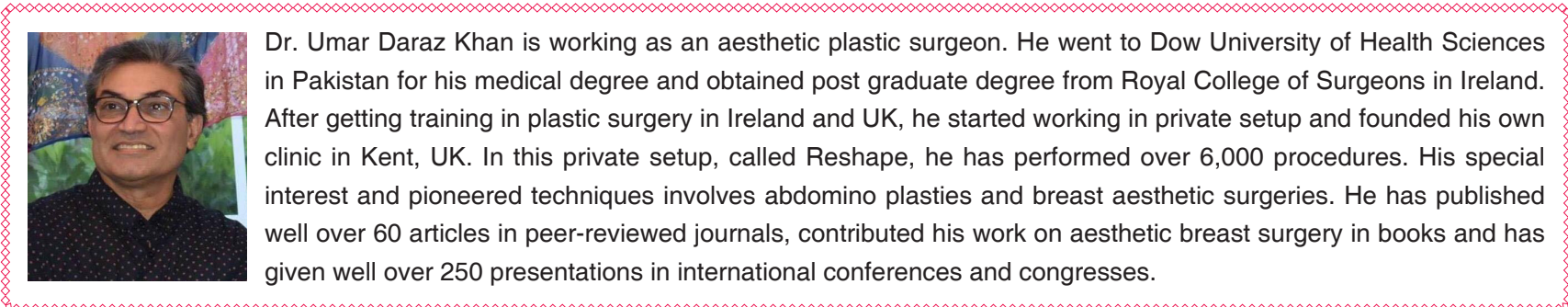

Article history:

Received: 18-05-2017

Accepted: 06-07-2017

Published: 19-07-2017

Key words:

Breast ptosis,

breast asymmetries,

muscle splitting biplane breast

augmentation,

muscle splitting mastopexy,

multiplane internal mastopexy

\begin{abstract}
Aim: To assess volume management in patients presenting with breast asymmetry and ptosis. Methods: Retrospectively collected data was analysed. The patients were divided into 3 groups. Group A included patients who had volumetric difference alone and had different size implants alone. Group B included patients who had volumetric difference with breast ptosis requiring mastopexy with different size implants. Group C included patients who presented with breast asymmetry with ptosis and had same size implants on both sides with different volume breast reduction. Results: Subgroup A1 included 145 patients who had larger implants placed on right side. Subgroup A2 included 95 patients who had larger implants on the left side. Subgroup B1 included 7 patients who had larger implants on the right. Subgroup B2 included 13 patients who had larger implant on the left side. Subgroup C1 included 7 patients who had larger reduction on right side. Subgroup C2 included 11 patients who had larger reduction on left. Conclusion: When different volume implants are used, the vast majority of the patients do not require a volume difference of more than $60 \mathrm{~mL}$. When the breast is larger on the right then larger mean volumes are used on left side to offset the larger right breast.
\end{abstract}

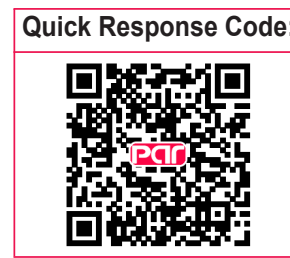




\section{INTRODUCTION}

Breast and chest asymmetries are common and have been documented in aesthetically perfect models as well as randomly selected females through public advertisement. ${ }^{[1,2]}$

Randomly selected patients presenting for augmentation mammoplasty had their preoperative pictures retrospectively analysed by independent observers. ${ }^{[3]}$ Breast and chest asymmetries also were prospectively recorded using detailed physical examination and measurements. Data was analysed and reported along with the relative prevalence and distribution of the larger side involved in these asymmetrical cases. ${ }^{[4]}$ All published articles in last 6 decades may have reflected from different angle highlighting various aspect and asymmetries of chest and breasts but one thing was commonly shared by all these authors was that breast and chest asymmetries are very common. However there is a lack of information on different volume implants used or different volume reductions performed for the management of these asymmetries when these patients presents for augmentation mammoplasty or one stage augmentation mammoplasty with mastopexy. The current article highlights volume management in 278 such patients who had different size implants or different weight tissue resection for asymmetry correction.

\section{METHODS}

In current study for breast volume difference management, retrospectively collected data was analysed. All patients had round cohesive gel textured implants placed in muscle splitting biplaner pocket and single surgeon consecutively performed all surgeries. Patients presenting with breast asymmetry requiring different size implants alone, mastopexy with different size implants and same size implants with different breast volume reduction for mastopexy were selected.

The patients were divided into 3 groups. Group A included patients who had volumetric difference without ptosis and were treated with different size implants alone. Group A was further divided into A1 receiving larger of the 2 implants on the right side and $A 2$ receiving larger of the 2 implants on the left side. Group B patients included who had volumetric difference along with breast ptosis or nipple level difference. The group was treated using different size implants for volume correction with similar size tissue resection for mastopexy. This group was further divided into B1 and B2. B1 included patients who had larger size implants on the right hand side and B2 included patients with larger implants placed on the left hand side. Group C included patients who presented with breast asymmetry with ptosis and had same size implants on both sides with different volume breast reduction on one side to correct asymmetry. Group C was further divided into $\mathrm{C} 1$ and $\mathrm{C} 2$. $\mathrm{C} 1$ included patients who had more tissue removed from right side than the left and C2 included patients who had more tissue removed from the left side.

\section{Statistical analysis}

The data were analyzed using the Statistical Package for the Social Sciences (SPSS), version 19.0. The results are presented in the text as frequency, percentage for qualitative/categorical variable (smoking, difference in implant size) and mean \pm SD for quantitative/continuous variables (age, implant size, and tissue removed, etc.). The statistical analysis was performed using the Chi-square test of proportion for the comparison of qualitative/categorical variables and the t-test for the comparison of quantitative/ continuous variables. A $P$-value $<0.05$ was assumed to be statistically significant.

\section{RESULTS}

Since 2005, 1,450 patients had augmentation mammoplasty and 150 patients had augmentation mammoplasty with mastopexy in muscle splitting biplane pocket. Of these 1,600 patients, 278 patients presented with significantly noticeable asymmetry and were operated for augmentation mammoplasty alone or augmentation mammoplasty with mastopexy.

\section{Group A}

Of 1,450 patients who had augmentation mammoplasty alone, 240 patients presented with significantly noticeable breast volume asymmetries without noticeable nipple level asymmetries or ptosis. Mean age of patients was $29.3 \pm 7.9$ years (range 18-53 years). Mean size of the implant on the right side was $343.4 \pm 66.2 \mathrm{~mL}$ (range 200-605 mL) and the mean size of implants on the left side was $352.9 \pm$ $86.5 \mathrm{~mL}$ (range 170-655 mL). There was no statistical difference when mean implant size of symmetrical augmentation mammoplasty was compared with mean implant size used on right or left side in patients with asymmetrical breasts $(P=0.650$ and 0.052 respectively) [Tables 1 and 2].

This group was further divided into $A 1$ and $A 2$. Subgroup A1 included 145 patients who had larger implants placed on right side. In this group of patients, mean implant size used on the right was $358.6 \pm 63.3 \mathrm{~mL}$ as compared to $317.0 \pm 62.5 \mathrm{~mL}$ on the left side. Subgroup A2 included 95 patients who had larger 
Table 1: Average distribution of age and size of the implants used in 240 patients who presented with asymmetrical breasts and compared with the mean age and size of implants used in 1,210 symmetrical breasts

\begin{tabular}{lccc}
\hline & $\begin{array}{c}\text { Same size implants } \\
(\boldsymbol{n}=\mathbf{1 , 2 1 0 )}\end{array}$ & $\begin{array}{c}\text { Different size implants } \\
(\boldsymbol{n}=\mathbf{2 4 0 )}\end{array}$ \\
\hline Age (years) & & \multicolumn{2}{c}{. } \\
Range & $18-67$ & \multicolumn{2}{c}{$18-53$} \\
Mean \pm SD & $29.7 \pm 8.71$ & \multicolumn{2}{c}{$29.3 \pm 7.94$} \\
Implant size $(\mathrm{mL})$ & & Right & Left \\
Range & $170-700$ & $200-605$ & $170-655$ \\
Mean \pm SD & $341.5 \pm 57.96$ & $343.4 \pm 66.24$ & $352.9 \pm 86.56$ \\
\hline
\end{tabular}

Table 3: Relative distribution and comparative analysis of implants used in asymmetrical breasts

\begin{tabular}{lccc}
\hline & $\begin{array}{c}\text { Implants on } \\
\text { right side }(\mathbf{m L})\end{array}$ & $\begin{array}{c}\text { Implants on } \\
\text { left side }(\mathbf{m L})\end{array}$ & $\boldsymbol{P}$ value \\
\hline Group A1 $(n=145)$ & $358.6 \pm 63.37$ & $317.0 \pm 62.51$ & 0.001 \\
Group A2 $(n=95)$ & $329.3 \pm 64.09$ & $407.8 \pm 89.53$ & 0.001 \\
\hline
\end{tabular}

implants on the left side. In this group, mean size of the implants on the left was $407.8 \pm 89.5 \mathrm{~mL}$ as compared to $329.3 \pm 64.1 \mathrm{~mL}$ on the right side. There was a significant statistical difference between the sizes of the implants used on the two sides in both subgroups ( $P=0.001$ and 0.001 respectively) [Table 3 and Figures 1 and 2].

\section{Group B}

Of 137 augmentation mammoplasty with mastopexy, 20 patients presented with significant asymmetry of breasts and treated with different size implants with same size breast tissue reduction. The group had a mean age of $31.6 \pm 10.1$ years (range 18-51 years).
Table 2: Comparative analysis of implants sizes used in patients with symmetrical and asymmetrical breasts who were treated with mammoplasty alone

\begin{tabular}{|c|c|c|c|}
\hline & $\begin{array}{c}\text { Symmetrical } \\
\text { breasts }(n=1,210)\end{array}$ & Asymmetrical breasts & $\begin{array}{c}P \\
\text { value }\end{array}$ \\
\hline & & $\begin{array}{l}\text { Average size of implants } \\
\text { used on right }(n=240)\end{array}$ & \\
\hline Range (mL) & $170-700$ & $200-605$ & \\
\hline \multirow[t]{2}{*}{ Mean \pm SD } & $341.5 \pm 57.96$ & $343.4 \pm 66.24$ & 0.650 \\
\hline & $\begin{array}{l}\text { Same size implants } \\
\qquad(n=1,210)\end{array}$ & $\begin{array}{l}\text { Average size of implants } \\
\text { used on left }(n=240)\end{array}$ & \\
\hline Range (mL) & $170-700$ & $170-655$ & \\
\hline Mean \pm SD & $341.5 \pm 57.96$ & $352.9 \pm 86.56$ & 0.052 \\
\hline
\end{tabular}

Mean size implants used was $314.0 \pm 75.1 \mathrm{~mL}$ (range 200-495 mL) on right and $339.0 \pm 99.7 \mathrm{~mL}$ on left.

This group was further divided into B1 and B2. Subgroup B1 included 7 patients who had larger implants on the right. In this subgroup, mean size of the implant on the right side was $334.0 \pm 52.2 \mathrm{~mL}$ as compared to $270.0 \pm 42.7 \mathrm{~mL}$ on the left side. There was a statistical difference between the implant sizes used on two sides $(P=0.027)$. Subgroup B2 included 13 patients who had larger implant on the left side and mean size in this subgroup was $377.0 \pm 102.4 \mathrm{~mL}$ on left as compared to $297.0 \pm 82.1 \mathrm{~mL}$ on the right. There was a statistical difference on the two sides $(P$ $=0.037)$ [Tables 4 and 5].

\section{Group C}

Of the 150 augmentation mastopexy, 18 patients presented with significant asymmetry with ptosis and had same size implants with more tissue removed
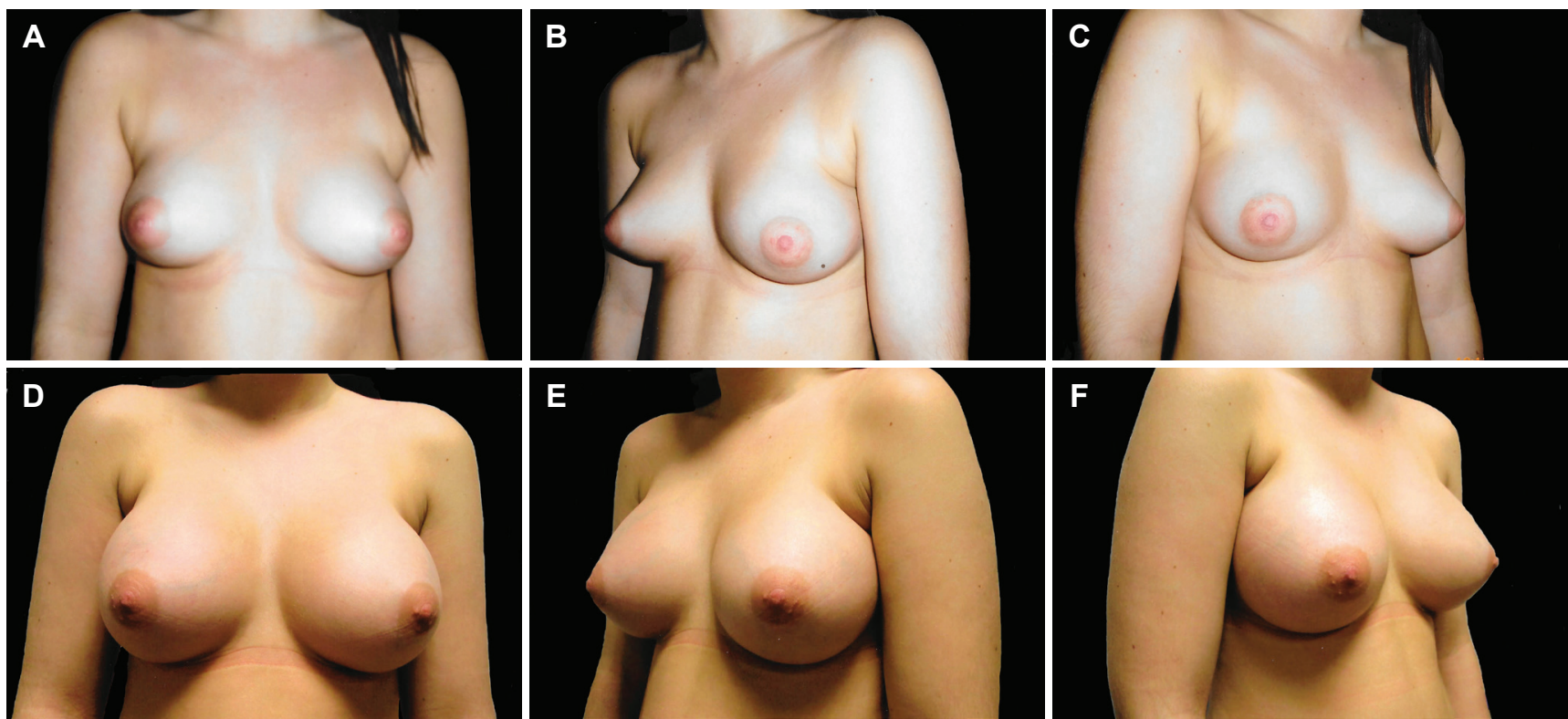

Figure 1: (A-C) A 23-year-old patient with moderate asymmetry of breast with no nipple level asymmetry. Her left breast is moderately larger than right; (D-F) 6 months postoperative views showing results following $330 \mathrm{~mL}$ and $360 \mathrm{~mL}$ high profile round textured cohesive gel silicone implants on her left and right side respectively 
Table 4: Comparison of average size implants used in symmetrical breasts with ptosis and that of average size implants used in asymmetrical breasts requiring mastopexy with different size implants with same volume tissue reduction (group B)

\begin{tabular}{lccc}
\hline & $\begin{array}{c}\text { Symmetrical breasts } \\
\text { with ptosis }(\boldsymbol{n}=117)\end{array}$ & $\begin{array}{c}\text { Asymmetrical } \\
\text { breasts with ptosis } \\
\text { Average size of implants } \\
\text { used on right }(n=20)\end{array}$ \\
value \\
Range $(\mathrm{mL})$ & $170-800$ & $200-495$ \\
Mean \pm SD & $302 \pm 87.1$ & $314 \pm 75.1$ & 0.563 \\
& $\begin{array}{c}\boldsymbol{P} \\
\text { Same size implants } \\
(n=117)\end{array}$ & $\begin{array}{c}\text { Average size of implants } \\
\text { used on left }(n=20)\end{array}$ \\
Range $(\mathrm{mL})$ & $170-800$ & $200-615$ & \\
Mean \pm SD & $302 \pm 87.1$ & $339 \pm 99.7$ & 0.088 \\
\hline
\end{tabular}

from one of the two sides for breast volume asymmetry correction $(>20 \mathrm{~g})$. Mean tissue excised from right side was $114.0 \pm 172.1 \mathrm{~g}$ as compared to $124.0 \pm$ $107.8 \mathrm{~g}$ on the left. There was no statistical difference between the tissues removed from two sides $(P=$ 0.835) [Figures 3 and 4].

The group was further subdivided in $\mathrm{C} 1$ and $\mathrm{C} 2$. Subgroup $\mathrm{C} 1$ included 7 patients who had larger breasts on right side and had more tissue removed from their right side (>20 g). Mean weight of tissue excised from the right side was $276.0 \pm 265.9 \mathrm{~g}$ as compared to $181.0 \pm 185.8 \mathrm{~g}$ on left side. There was no statistical difference on the breast tissue removed from two sides in this group $(P=0.530)$. Subgroup C2 included 11 patients who had larger breast on left and more tissue excised from left side. In this group mean weight of the tissue removed from left side was $105.0 \pm 44.6 \mathrm{~g}$ as compared to $49.0 \pm 24.5 \mathrm{~g}$ on right.
Table 5: Comparative analysis and relative distribution of different size implants used in asymmetrical breasts with ptosis (group B1 and B2)

\begin{tabular}{lccc}
\hline & \multicolumn{2}{c}{ Larger implant used on } & \multirow{2}{*}{$\boldsymbol{P}$ value } \\
\cline { 2 - 3 } & Right $(\mathbf{m L})$ & Left $(\mathbf{m L})$ & \\
\hline Group B1 $(n=7)$ & $334 \pm 52.2$ & $270 \pm 42.7$ & 0.027 \\
Group B2 $(n=13)$ & $297 \pm 82.1$ & $377 \pm 102.4$ & 0.037 \\
\hline
\end{tabular}

Statistical analysis was significant on two sides $(P=$ 0.001) [Table 6].

\section{DISCUSSION}

Chest and breast asymmetries are very common and its prevalence has been reported in retrospective and prospective studies. ${ }^{[1-4]}$ The reported incidence of prospective clinical examination showed volume and nipple areolar level difference of $46.6 \%$ and $32.6 \%$ respectively and were significantly noticeable on left. ${ }^{[4]}$ Chest and breast asymmetries were also noted in $88 \%$ of patients ${ }^{[3]}$ and a combination of manual and 3D photography showed $81.7 \%$ soft tissue volumetric differences and when these soft differences were combined with chest bony asymmetries, incidences of asymmetry rose to $100 \% .{ }^{[5]}$ Another commonly overlooked asymmetry is asymmetrically placed nipple areolar complex in horizontal axis ${ }^{[6]}$ However none of the above studies gave details of volume difference management. ${ }^{[3-6]}$

Augmentation mammoplasty when performed alone or as a single stage breast augmentation with mastopexy has shown an acceptable results. ${ }^{[7-9]}$ However,
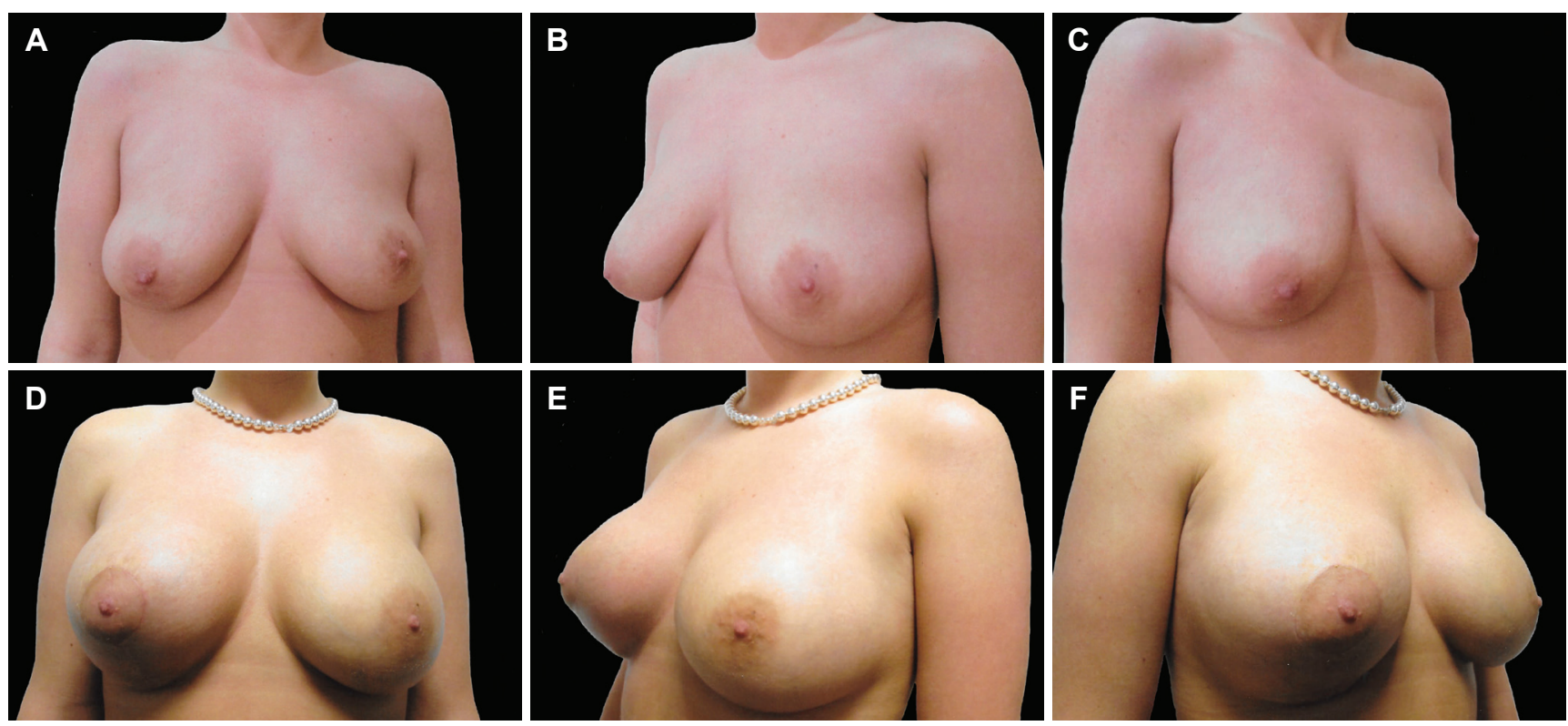

Figure 2: (A-C) A 25-year-old patient with class B and A ptosis on her right and left side respectively along with breast asymmetry; (D-F) 8 months following single stage right vertical scar mastopexy with $35 \mathrm{~g}$ tissue resection from her right side. She had $260 \mathrm{~mL}$ round textured moderate profile implants bilaterally 
Table 6: Over all mean tissue resection from each side in group $\mathrm{C}$, as well as respective mean tissue resection from each breast when breast were larger on either right (C1) or left side (C2)

\begin{tabular}{|c|c|c|c|}
\hline & Right breast & Left breast & $P$ value \\
\hline $\begin{array}{l}\text { Average tissue resection } \\
\text { from asymmetrical breasts } \\
(n=18)\end{array}$ & $114 \pm 172.1$ & $124 \pm 107.8$ & 0.835 \\
\hline $\begin{array}{l}\text { More tissue resected from } \\
\text { right bigger breast (group } \\
\mathrm{C} 1, n=7 \text { ) }\end{array}$ & $276 \pm 265.9$ & $181 \pm 185.8$ & 0.530 \\
\hline $\begin{array}{l}\text { More tissue resected from } \\
\text { left bigger breasts (group } \\
\text { C2, } n=11 \text { ) }\end{array}$ & $49 \pm 24.5$ & $105 \pm 44.6$ & 0.001 \\
\hline
\end{tabular}

studies did not include details for volume difference management in asymmetrical breasts even though the most common reason for implant related revision noted was change of size of implant. ${ }^{[9,10]}$ A good interactive process of preoperative sizing for implants is effective and can avoid revisional surgery. ${ }^{[11,12]} \mathrm{A}$ more rigid high five or more scientific and accurate way is to use 3-D photography combined with measurements of patients. ${ }^{[5,13]}$ However a rigid five point system or 3-D photography without patient's participation can leave the subject unhappy. In author's practice, a trial of fixed volume implants in a desired size brassiere is practical and effective and revision rates of less than $1 \%$ was reported. ${ }^{[14]}$ After carrying out a careful examination of chest, breast and tissue characteristics, different size and profile implants are placed in a desired size bra until surgeon and patients agree on the size and symmetry of breasts. Those who presents with breast asymmetry with ptosis, patients are given the choice to have either similar size implants with more tissue resection from larger breast or having same amount of tissue reduced from both sides with different size implants. There is an advantage of asymmetrical breast tissue reduction and use of same size implants. In case, a patient gains or loses weight in future, breast volume is likely to go up or down in similar proportions without reintroducing asymmetry. However when two different size implants are used leaving original breast asymmetry unaddressed, patient's weight changes may accentuate original breast volumetric differences. The use of fixed-volume implants for asymmetry correction has shown low revision rate. ${ }^{[14-17]}$ Other commonly used options are adjustable breast implants or intraoperative sizers. ${ }^{[18,19]}$ In more complex deformities, more complex surgical procedures are required. ${ }^{[20]}$

Analysis of the current study has shown some interesting results. In group $A$ that required asymmetry correction using different size implants only, out of 240 patients, $145(60 \%)$ breasts were larger on the left showing a relative predisposition of left side to be larger as reported in earlier studies. ${ }^{[4,14]}$ When different sizes implants were used on two sides in group A (A1 and $A 2$ ) and compared with the size of the implants used in symmetrical breasts, there was no statistical difference between the sizes of implants used in each group [Table 2]. However when the implants sizes were compared on two sides in patients with asymmetry, the difference in breast implant sizes was significant [Table 3]. Also, when the right breast is larger, the difference is likely to be more noticeable requiring larger average volume for correction on
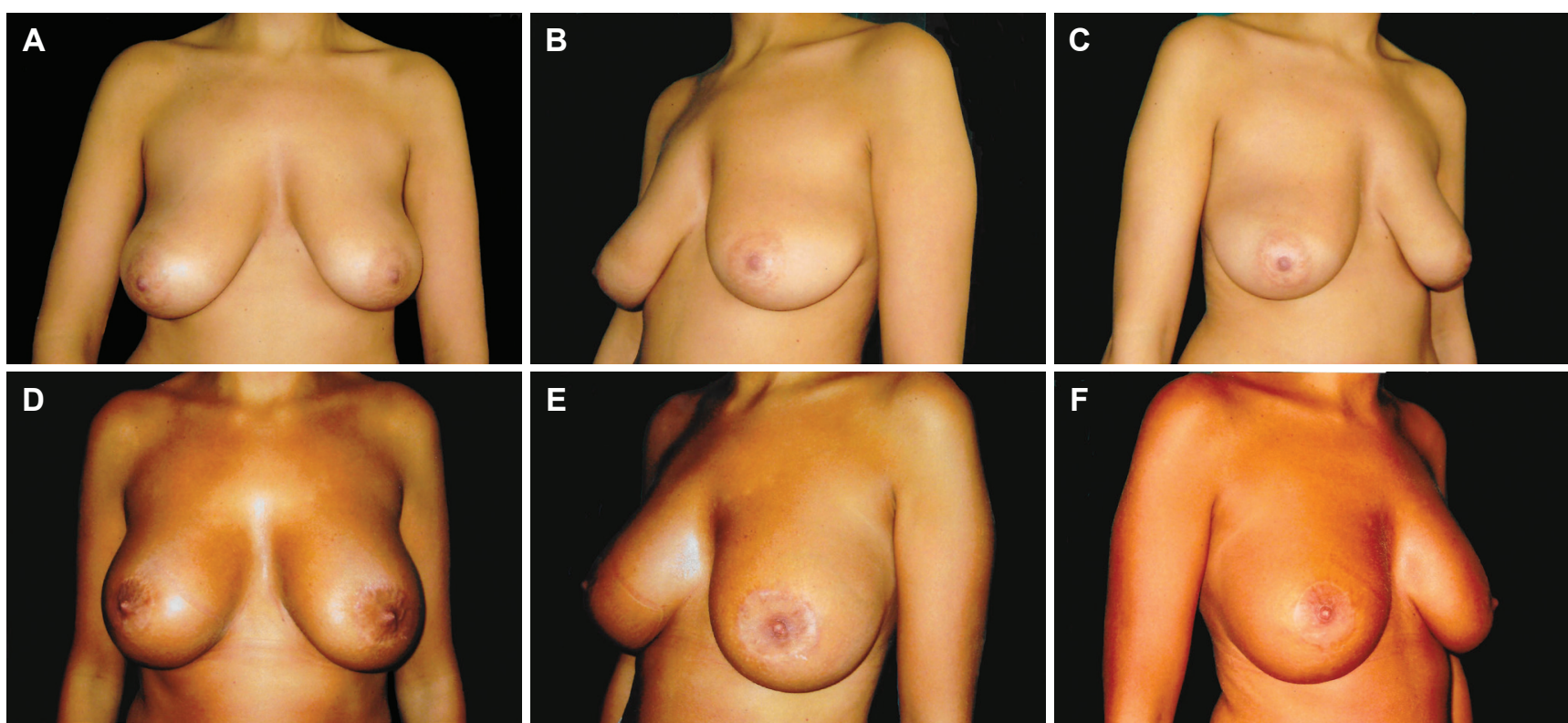

Figure 3: (A-C) A 29-year-old patient who presented with bilateral breast asymmetry with associated class $\mathrm{C}$ ptosis on her right and class $B$ ptosis on her left side; (D-F) 8 months following right vertical scar and left periareolar mastopexy. She had $255 \mathrm{~mL}$ moderate profile round textured cohesive gel silicone implants. She had $55 \mathrm{~g}$ tissue removed from right side as compared to $12 \mathrm{~g}$ from her left side 
Table 7: Relative incidence of larger volume implant used on respective sides based on the volume of the prosthesis used in asymmetrical breasts

\begin{tabular}{lccc}
\hline $\begin{array}{l}\text { Difference } \\
(\mathbf{m L})\end{array}$ & $\begin{array}{l}\text { Implant bigger right } \\
\text { A1 }(\boldsymbol{n}=\mathbf{1 4 5})\end{array}$ & $\begin{array}{c}\text { Implant bigger left } \\
\text { A2 }(\boldsymbol{n}=\mathbf{9 5})\end{array}$ & $\begin{array}{c}\boldsymbol{P} \\
\text { value }\end{array}$ \\
\hline$<30$ & $31(21.4 \%)$ & $20(21.1 \%)$ & 0.951 \\
$30-60$ & $96(66.2 \%)$ & $38(40.0 \%)$ & 0.001 \\
$>60$ & $18(12.4 \%)$ & $37(38.9 \%)$ & 0.001 \\
\hline
\end{tabular}

smaller left breast (mean volume $407.8 \mathrm{~mL}$ ) as compared to the volume of implant used on the right side to correct asymmetry when left breast is larger (mean volume $317.0 \mathrm{~mL}$ ) [Table 3]. Similarly when left breast is larger, only $12.4 \%$ patients had larger than $60 \mathrm{~mL}$ implants on the right breast as compared to $38.9 \%$ requiring more than $60 \mathrm{~mL}$ difference implant on the opposite side when right breast was larger. The results again concurred with the previously published work [Table 7]. [14]

As one would expect, patient requiring mastopexy with augmentation mammoplasty have in general or present with larger breasts than patients who require augmentation mammoplasty alone. The latter group is generally hypoplastic as compared to those patients requesting for augmentation mammoplasty and mastopexy due to excess breast skin and excess breast tissue accompanied with ptosis. It was expected that relatively higher prevalence of larger breast be on right than on left side. When the sizes of the implants in this group was analysed, it was noted that slightly larger mean size implant $(339 \mathrm{~mL})$ was needed on left breast to compensate right larger side breast (B2) when compared with the mean size implant $(314 \mathrm{~mL})$ used on the right side to compensate left larger breast (B1). This also was noted that mastopexy requiring augmentation mammoplasty, larger mean size implants in group B2 were used on the left side in 13 patients with a larger difference $(80 \mathrm{~mL})$ as compared to 7 patients in group B1, where larger implant was used on the right with smaller difference $(64 \mathrm{~mL})$ to compensate larger breasts on the left side.

The weight of tissue resection was also analysed in 18 patients (group C) presenting with noticeable breast asymmetry requiring mastopexy with augmentation mammoplasty. These patients had same size implants with more tissue removed from the larger side (> $20 \mathrm{~g}$ ). This was noted that when the breast was larger on the right side, the mean weight of the tissue removed was $95 \mathrm{~g}$ more as compared to $56 \mathrm{~g}$, when left breast needed reduction for symmetry. The result emphasize that when the breast is larger on the right, it tends to be relatively larger than patients presenting with larger breast on the left side [Table 6].

Volume difference in asymmetrical breasts can be assessed preoperatively using 3D photograpgy ${ }^{[5]}$ or retrospectively by analyzing the volume difference of the implants used on two sides in patients who presented with asymmetrical breasts and had augmentation mammoplasty without mastopexy. The volume difference can also be analysed in patients who needed augmentation mammoplasty with mastopexy. In the latter group, volume difference of the implants can be analysed when two different size
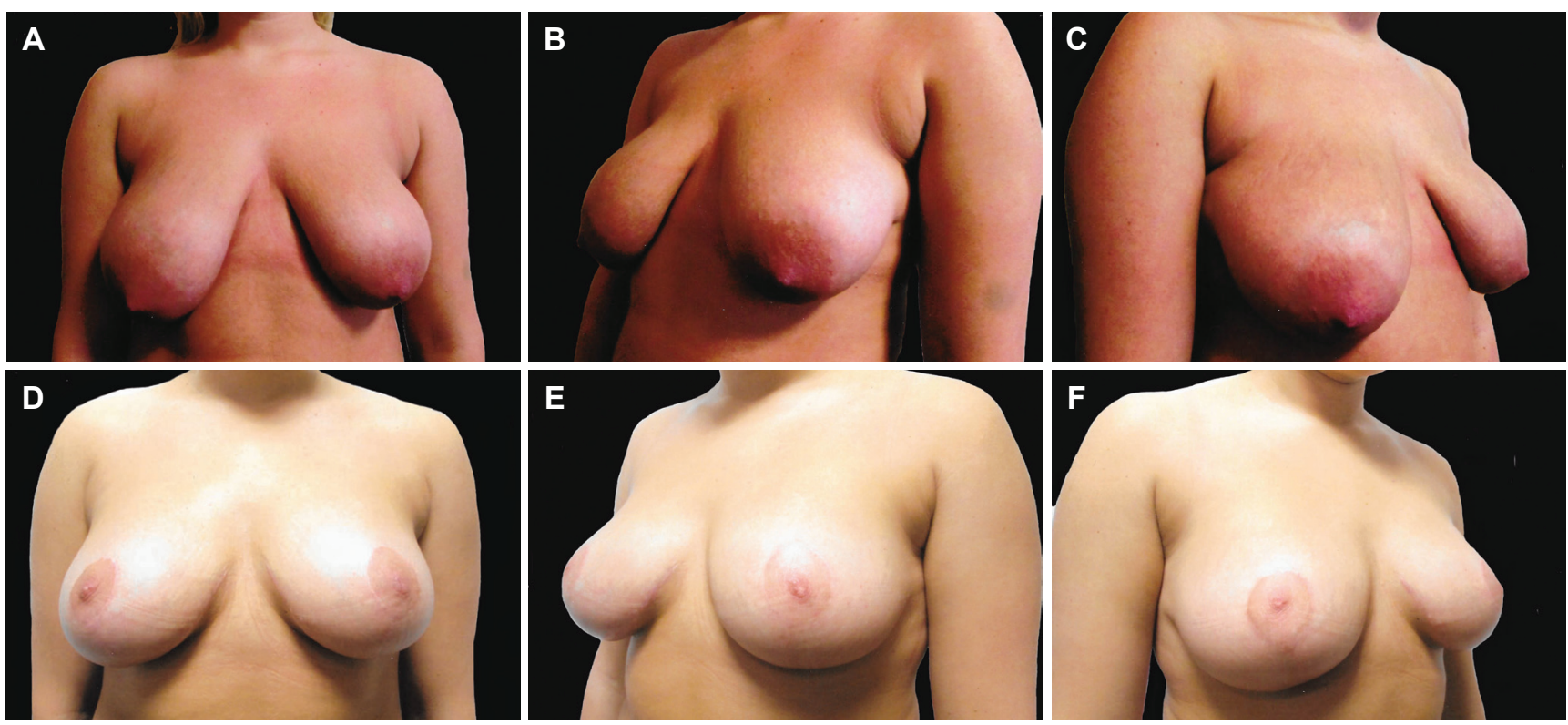

Figure 4: (A-C) A 19-year-old patient presenting with breast hypertrophy, asymmetry and bilateral class $C$ ptosis. Her right breast was markedly larger than the left; (D-F) postoperative results 10 months following Wise pattern mastopexy with $230 \mathrm{~mL}$ round low profile textured cohesive gel silicone implants. She had $173 \mathrm{~g}$ tissue removed from her right and $147 \mathrm{~g}$ tissue removed from her left breast 
implants were used with similar breast tissue reduction or where two different weight tissue reductions were performed with same size implants. In author's opinion 3D photography is a more scientific and accurate tool to evaluate the difference as it measures the difference of chest wall asymmetry as well as breast volume asymmetry. Use of 3D photography has shown an incidence of $100 \%$ asymmetries and comprised of soft tissue, chest wall and combined soft tissue and chest wall asymmetries. The breakdown of volumetric differences was also reported in the study. The article noted a difference of $0-10 \mathrm{~mL}$ in $2.2 \%, 11-25 \mathrm{~mL}$ in $21.9 \%, 26-50 \mathrm{~mL}$ in $28.9 \%, 51-100 \mathrm{~mL}$ in $29.3 \%$ and $>101 \mathrm{~mL}$ in $17.7 \%$ of the females. However revision rate for the size or shape of the implants was not reported in the study neither the relative distribution of larger size breast, chest or combined asymmetries of the two. ${ }^{[5]}$ In a previously published author's article, a retrospective analysis of the volume differences in 146 augmentations mammoplasties showed twice as many patients needing larger implants on the right side to compensate larger breast on the left. Less mean volume was needed on the right side to compensate left larger breasts than the mean volume used on the left side to offset larger breast on the right. In the same study $0-30 \mathrm{~mL}$ volume difference was needed in $35.6 \%, 31-60 \mathrm{~mL}$ difference was used in $48.6 \%$, $60-90 \mathrm{~mL}$ difference was used in $7.5 \%$ and $>90 \mathrm{~mL}$ difference was used in $8.2 \%$ of the patients. There was only one patient who required revision surgery for size change on one side. ${ }^{[14]}$ Sample included patients who had augmentation mammoplasties alone, all patients were operated by the same surgeon using muscle splitting technique for implant pocket. In current study, asymmetries of breasts requiring augmentation and mastopexy were added to augmentation mammoplasty group. It was again noted that when asymmetries are present, left breast was larger in majority of the patients. In subgroup A1 with larger left breasts, $87.6 \%$ needed implants with a difference of less than $60 \mathrm{~mL}$ as compared to $61.1 \%$ in subgroup A2 with larger right breasts. Similarly, when a volume greater than $60 \mathrm{~mL}$ was needed to compensate for size difference, it was mostly needed on left side for the right larger breasts [Table 7]. ${ }^{[14]}$

There are many approaches to assess and manage breast and chest asymmetries. The options include preoperative planning using 3D photography or simple examination and measurements of breasts. Intra operative management includes use of sizers and adjustable implants. Despite of the various measures taken to achieve symmetry in breast asymmetries, it is not guaranteed that a perfect result can be achieved in all cases. Some degree or level of differences are likely to persist and that a patients should be warned of this residual asymmetry. In the author's opinion and practice, careful examination and measurements are the most time efficient, cost effective and reproducible method. In this series of 278 , only one patient was unhappy with the postoperative results requiring revision surgery for implant volume difference readjustment. High profile implants of different sizes are the choice for patients requiring volume adjustment alone. Those patients who present with asymmetry of skin excess, breast volume and ptosis requiring one stage mastopexy and augmentation, moderate profile implants is the choice of author. Combination of different profiles implants is seldom required and limited to patient who present with hemithoracic disjunction or noticeable anteroposterior chest dimension asymmetry with or without breast volume asymmetry. ${ }^{[4,14]}$

In conclusion, breast and chest asymmetries are very common. The left breast or chest or both are likely to be larger than the right chest, breast or both. Not all patients request or require different size implants. When different volume implants are used, the vast majority the patients do not require a volume difference of more than $60 \mathrm{~mL}$. When the breast is larger on the right then larger mean volumes are used on left side to offset the larger right breast.

\section{Authors' contributions}

U.D. Khan contributed solely to this paper.

\section{Financial support and sponsorship}

Author has no financial interests in any of the products or devices used in this retrospective study.

\section{Conflicts of interest}

Author declares no potential conflict of interest with respect to the research, authorship and publication of the article.

\section{Patient consent}

All patients signed an informed consent form.

\section{Ethics approval}

This is a retrospective data analysis of procedures performed in a private centre therefore international review board approval was not required. All procedures were performed in accordance with the ethical standards of the 1964 Declaration of Helsinki.

\section{REFERENCES}

1. Penn J. Breast reduction. Br J Plast Surg 1955;7:357-71.

2. Smith DJ Jr, Palin WE Jr, Katch VL, Bennett JE. Breast volume and anthropomorphic measurements: normal values. Plast Reconstr Surg 
1986;78:331-5.

3. Rohrich RJ, Hartley W, Brown S. Incidence of breast and chest wall asymmetry in breast augmentation: a retrospective analysis of 100 patients. Plast Reconstr Surg 2005;115:1039-50.

4. Khan UD. Breast and chest asymmteries: classification and relative distribution of common asymmteries in patients requesting augmentation mammoplasty. Eur J Plast Surg 2011;34:375-85.

5. Gabriel A, Fritzche S, Creasman C, Baqai W, Mordaunt D, Maxwell $\mathrm{P}$. Incidence of breast and chest wall asymmteries: 4D photography. Aesthet Surg J 2011;31:506-10.

6. Khan UD. Breast augmentation in asymmetrically placed nipple areolar complex in horizontal axis: lateralization of implant pocket to offset laterlised nipple. Aesthetic Plast Surg 2009;33:591-6.

7. Khan UD. Muscle splitting, subglandular and partial submuscular augmentation mammoplastoies: 12-year retrospective analysis of 2026 primary cases. Aesthetic Plast Surg 2013;37:290-302.

8. Khan UD. Augmentation mastopexy and augmentation mammoplasty: an analysis of 1,406 consecutive cases. Plast Aesthet Res 2016;3:26-30.

9. Steven WG, Stoker DA, Freeman ME, Quardt SM, Hirsch EM, Cohen R. Is one-stage breast augmentation with mastopexy safe and effective? A review of 186 primary cases. Aesthet Surg J 2006;26:67481.

10. Spear SL, Pelletiere CV, Menon N. One-stage augmentation combined with mastopexy: aesthetic results and patient satisfaction. Aesthetic Plast Surg 2004;28:259-67.
11. Hidalgo DA, Spector JA. Preoperative sizing in breast augmentation Plast Reconstr Surg 2010;125:1781-7.

12. Khan UD. The impact or preoperative breast implant size selection on the 3-year reoipeation rate. Eur J Plast Surg 2013;36:503-10.

13. Tebbets JB, Adams WP. Five critical decisions in breast augmentation using five measurements in 5 minutes: the high five decision support system. Plast Reconstr Surg 2005;116:2005-16.

14. Khan UD. Review of implant sizes in 146 consective asymmetrical augmentation mammoplasties. Eur J Plast Surg 2014;37:273-80.

15. Maxwell GP. Breast asymmetry. Aesthet Surg J 2001;21:552-61.

16. Gallegos ML, Casas LA. A systematic, one-stage approach in the treatment of tuberous breast deformity. Aesthet Surg J 1998;18:431-8.

17. Arco A, Gravante G, Araco F, Gentile P, Castrif, Delago D, Fillingeri V. Breast asymmetries: a brief review and our experience. Aesthetic Plast Surg 2006;30:309-19

18. Becker H. Adjustable breast implants provide postoperative versatility. Aesthet Surg J 2000;20:332-4

19. Gore SM, Lamberty GH. Perthese implant-identical cohesive-ge sizers in breast augmentation: a prospective report on 200 consecutive cases and implications for treatment of breast asymmetry. Aesthet Surg J 2012;32:310-8

20. Yasilda AK, Sevin KZ, Sirvan SS, Karsidag S, Tatlidede HS. Our aurgical approach to treatment of congenital, developmental and acquired breast asymmetries: a review of 30 cases. Aesth Plast Surg $2013 ; 37: 77-87$ 